\title{
Empowering Voices, Transforming Communities
}

It is proposed that the axiom, 'indigenising the academy' means to make the academy both responsive and responsible to Indigenous people's goals of self-determination and wellbeing. This requires a huge effort by Indigenous scholars to be committed to transforming the academy. To engage in this work, requires a redefining of the academy from an agent of colonialism to a platform for decolonisation. This role requires Indigenous scholars to both individually and collectively establish a continuous, visible and active presence at tertiary institutions and to facilitate what bell hooks (1994: 12) refer to as "education as the practice of freedom."

This is no easy task because not only does the academy play a role in the colonisation of Indigenous peoples, but it has a huge investment in maintaining control over: who defines knowledge, who has access to knowledge and who produces knowledge. Therefore, it follows that should the Indigenous scholar adopt the responsibility to challenge the very foundation of the academy, they become a threat to the very power and authority claimed by the academy. Furthermore, these challenges to the academy are often based on the Indigenous scholars' unrelenting commitment to ensure that the collective interests of their people are sustained and that the Indigenous voice is accurately represented within the academy.

Paulo Freire (1993: 112) describes these people [in this case the Indigenous scholars] who work towards liberation as 'Revolutionary Leaders' who “. . . cannot think without the

Professor Ka'ai is Professor in Māori Innovation and Development at Te Ara Poutama, The Faculty of Māori Development and Director of Te Ipukarea - The National Māori Language Institute and the International Centre for Language Revitalisation at AUT University. 
people, nor for the people, but only with the people. The dominant elites, on the other hand, can - and do - think without the people - although they do not permit themselves the luxury of failing to think about the people in order to know them better and thus dominate them more efficiently". These struggles for recognition in the academy can, over time, erode the spirit, particularly as Indigenous scholars within mainstream higher education are usually a minority and are often dwarfed by the overwhelming numbers of nonIndigenous people.

\section{The Aotearoa/New Zealand Education Context}

Schooling in the smid-1800s in Aotearoa/New Zealand including university education, can only be described as a primary instrument for taming and civilising the natives and forging a nation which was connected at a concrete level with the historical and moral processes of Britain. Only seven years after the Treaty of Waitangi ${ }^{1}$ was signed in 1840 , the Crown introduced the 1847 Education Ordinance Act, which was a policy of assimilation. It is against this background that one can begin to understand why Māori, as the Indigenous people of Aotearoa/New Zealand, have struggled to have their language, culture and knowledge systems validated in dominant mainstream New Zealand education for almost 200 years.

It is against this background that I introduce you to Te Ipukarea as a construct which defies the colonial silo

Treaty of Waitangi is the founding document of Aotearoa/New Zealand. It was established as a partnership between the British Crown and Māori as the Indigenous people. It was signed on the 6th of February 1840 and has been the focus of controversy ever since. This has stemmed from the fact that two versions of the Treaty were produced. The Māori text which was signed by both Māori and the Crown was translated from the English text by a non-Indigenous missionary. However, the translation was not at all a correct interpretation of the English text. It is the English text which has been used by the Crown as the definitive version and this is the cause of contention to this day by both Maori and non-Māori. 
mentality and attitudes of universities and attracts participation and support from a range of Māori across tertiary institutions and community organisations who are motivated by Indigenous values and principles of sharing knowledge and expertise to ensure the Māori language and culture survive. Furthermore, we use digital technologies to maintain relationships, preserve, and archive, and share our knowledge for the benefit of future generations and the communities we serve.

\section{Te Ipukarea}

Te Ipukarea - The National Māori Language Institute was established in 2008 to promote excellence in scholarship, teaching and research in the Māori language. It is a collaboration of community and tertiary Māori language providers. The Institute addresses the need for a coordinated and determined approach to improving the effectiveness and efficiency of Māori language education and of raising the status of the language by taking full advantage of modern technologies. For example, one of the projects we have undertaken is called He Pātaka Mātauranga. It reflects the significance and validity of Māori knowledge and the importance of the role we place on the repositories of this knowledge. We brought together key repositories of Māori knowledge and language who were interviewed and recorded. Their interviews are streamed online and are free-to-access.

Housed inside the Institute is Te Whare o Rongomaurikura, The International Centre for Language Revitalisation. It grew out of a desire to respond to Indigenous groups around the world interested in the work being developed by Te Ipukarea for the revitalisation of the Māori language and in particular using technologies to revitalise their respective languages, some of which are endangered. Historically, there is a divide between Indigenous communities and universities. However, the Institute and the Centre do not 
perpetuate this. We reach out to communities and engage them in our work; a reflection of our commitment to empowering their voices thus transforming communities.

An example of this is the development of REO Online Language Learning Systems. REO is the Māori term for language and voice. REO was chosen for its simplicity and what it conveys in terms of providing a 'voice' for endangered languages. The system is designed on the basis that language learning is a social and community based activity. It is a system that can be customized to any language but requires participation of speakers of the language from the various language communities; this is an important feature of our work as we understand the value of establishing and maintaining relationships with and between Indigenous peoples. We are currently working with language groups within institutions, but we also work with communities such as the Salish from the Flathead Reservation in Montana and the Tapuika people from Aotearoa/New Zealand.

Te Ipukarea is a space for undertaking teaching and research which recovers our histories, reclaims our lands and resources, restores justice and preserves our language and traditions within a culturally specific framework called, Kaupapa Māori Ideology.. . . herein lies the theories generated by Indigenous scholars and tohunga [experts] who have constructed models to explain a Māori way of thinking (epistemology) and a Māori way of doing things within the western academy.

Therefore, Kaupapa Māori Ideology is best understood as a culturally specific framework. It is located in te ao Māori (the Māori world) and reflects the relationship Māori have to the land and the environment, to Māori socialisation patterns and cultural nuances and to Māori identity. It is a framework which is best understood by other Indigenous peoples as it corresponds philosophically with what underpins Indigenous peoples in colonised contexts, that is, their struggle for selfdetermination and the right to have their voices heard as they 
constantly fight against the disadvantaging consequences of the colonial legacy. It is Kaupapa Māori Ideology which underpins the management, core business, direction and practices of Te Ipukarea to the pulse of whakatepea te kō, a leadership which unites the people and focuses them on achieving the tasks at hand in a strategic way which benefits the collective and not simply the individual. It is difficult for non-Māori to fully comprehend the concept of Kaupapa Māori Ideology because they sit outside the Māori culture. Therefore, non-Māori are only able to interpret the culture through their own cultural lens and filters.

So how does Te Ipukarea find legitimacy within the academy and resist becoming the "Other" and being pushed to the margins or the periphery which is traditionally and historically Pākehā (non-Māori of European origin) in its design and hegemony? We simply undertake projects which reflect our cultural base and world view and we deliver this knowledge as much as we can in our own language using digital technologies which are free to access. These projects are underpinned by specific cultural markers.

- $\quad$ Tribal Identity

the importance of a sense of place and belonging through genealogical ties.

- Land and Landscape

the recognition of the need for respect, harmony, and balance by the people for the land and the resources it provides.

- $\quad$ Spirituality

based on a spiritual view of and response to the natural world.

- $\quad$ Elders

serve as a critical link to the past in the present context to ensure cultural practices and tribal knowledge remain intact for future generations.

- Language the recognition that the language contains so many cultural indicators that enrich one's identity.

- Indigenous Knowledge 
the importance of culturally determined ways of thinking, behaving, communicating and living as Indigenous people

- Diversity

the celebration of tribal identity and a rejection of nonIndigenous labels and definitions that homogenise Māori people.

- Kinship Structure

based on a collaborative/shared power system within social hierarchies.

- Self-determination

the recognition of the rights of Indigenous peoples to live as Indigenous people. To be healthy, Māori people need access to learning their language, to education and qualifications, to employment and to have their culture valued apropos of $\mathrm{Te}$ Tiriti o Waitangi. They need to be able to be active participants in determining their own future.

- Concept of time

the culture is structured to look to the past as a guide for the present and the future

- Cultural knowledge

this is viewed in a holistic framework where all aspects are interrelated

- $\quad$ Reciprocity

based on the view that mutual respect is the cornerstone of human relationships and between humans and the environment (Ka'ai \& Higgins 2004:23-24).

Furthermore:

- We integrate Indigenous ideologies within our work which anchor us within the academy and which give expression to our cultural imperatives.

- We utilise our own pedagogies which enhance our work such as residential and/or experiential learning, known as wānanga.

- We live our culture within the academy and take the time to integrate our cultural practices within our environment.

- We urge our students to value the language and culture and not to fall victim to the power of neo-colonialism and devalue the degrees we offer, dismissing them as useless and not leading to employment. 
- We are committed to succession planning to ensure that our students consider a career in academia which will result in the Institute and Centre remaining intact for future generations.

- We undertake research and publish works from our students and staff to demonstrate a commitment to research in recovering our histories, reclaiming our lands and resources, restoring justice and preserving our language and traditions within a culturally specific framework.

- We observe Indigenous research ethics when undertaking all research projects.

- We utilize digital technologies in the archiving and dissemination of Māori knowledge to increase their accessibility. These are free to access.

Underpinning all of these principles and actions is a set of commonalities shared amongst Indigenous people situated in historically subordinated circumstances. These commonalities are also associated with a broader sense of commitment to self- determination and community agenda and the struggle for legitimacy and cultural integrity. Such commonalities bind Indigenous people globally:

- an over-riding sense of commitment to the collective interest of the Indigenous

- community with which they are associated

- the relationship between academic studies and the 'real world'

- the participatory nature of the Indigenous community which includes elders as repositories of knowledge and the transmission of traditional beliefs, values, skills and customs

- the role that spirituality plays in the sense of attending to the development and well-being of the whole person

- a commitment to the survival and use of the Indigenous language

- understanding and respect for the Indigenous world view

- traditional ways of constructing, organising and using knowledge that is, Indigenous epistemologies or ways of knowing. (Ka'ai 2000:12-21).

These commonalities inform the work of the International 
Centre for Language Revitalisation and position us to engage with Indigenous communities globally in supporting the revitalization of their respective languages.

\section{Indigenous Scholars as Agents of Change}

Māori remain frustrated as a Treaty partner, as current government policies continue to marginalise and exclude Māori from political decision-making in determining the physical, economic, educational, social and philosophical development of Aotearoa/New Zealand thus heightening Māori opinion that they/we are being pushed to the periphery to operate on the fringes of society. Similarly, Cornell West who advocates for African American rights states:

If affirmative action disappears from the American scene, many blacks will still excel and succeed. But the larger signal that sends will be lethal for the country. It is a signal that white supremacy now has one less constraint and black people have one more reason to lose trust in the promise of American democracy (West 1999: 498).

So where does this leave the Indigenous scholar in Aotearoa/New Zealand? As Indigenous Māori scholars we need to reclaim our epistemologies, our pedagogies, our cultural imperatives and our language. We must challenge the 'cultural conquest' mentality of mainstream education including universities. We need to demonstrate to these institutions that we will never trade on our own identity as a commodity; that our identity is not for sale! Furthermore, we have to resist the constant pressure to conform to the "culture" of the academy and the dominant majority and create new and safe spaces for Indigenous people to flourish within the academy. Devon Abbott Mihesuah and Angela Cavendar Wilson expressed their frustration with this as Indigenous First Nations women in their statement, 
Some of us wonder daily if we might be more useful, more productive, and more successful if we removed ourselves from the academy and continued our research, writing and scholarship in other arenas. Some of us feel as though we can only beat our heads against the wall so many times before the damage to our spirits outweighs whatever small gains we might be making within institutions that do not value our contributions. However, we recognize that this generation of Indigenous scholars is not the first to engage in such struggles (Mihesuah and Cavendar 2004: 6-7).

As a critical mass of Indigenous scholars begins to emerge, we need to ensure that the task of 'indigenising the academy' is shared across the group and provide a bigger voice in asserting our rights to live as Indigenes, to practice our beliefs and cultural traditions, to teach our knowledge and to speak our own language in our own spaces within the academy.

Historically, universities in Aotearoa/New Zealand have enjoyed positions of elitism, as their academics and researchers ran rampant through Māori communities, selecting certain information, critiquing and analysing, and writing about Māori from their own world views and perspectives. However, the recent emergence of Māori academics and the establishment of Indigenous Institutes such as Te Ipukarea, has signaled a clear challenge to the academic community that the socially constructed hierarchical knowledge categorisation and belief systems that reside within university contexts, can no longer be taken for granted as being the only valid knowledge system. The very idea about knowledge, the ethics, morality and processes associated with information collection, the ways in which knowledge is transmitted, presented and represented, and even "what counts as knowledge" are all processes that are currently being struggled over and contested (Johnston, 2004: 3-4).

As Indigenous scholars globally, we need to continue the leadership in the fight for our right to be Indigenous within the 
academy and that in order to fulfill the central role in the university that our disciplines, or in our case, our Institute, should have, they need to be resourced adequately to undertake research informed teaching and quality research that will contribute to the development of our respective nation's and its peoples. As Indigenous scholars, we need to inspire our children and communities and teach them to value their heritage and their cultural identity and resist being seduced and controlled by the dominant culture. In the words of bell hooks:

... I add my voice to the collective call for renewal and rejuvenation in our teaching practices. Urging all of us to open our minds and hearts so that we can know beyond the boundaries of what is acceptable, so that we can think and rethink, so that we can create new visions, I celebrate teaching that enables transgressions - a movement against and beyond the boundaries. It is that movement which makes education the practice of freedom (hooks 1994: 12).

Te Ipukarea and the International Centre for Language Revitalisation, together with the local and global networks that we have established, are indeed exemplars of agents of change within the academy committed to transforming both the academy and the communities we serve. This after all is our duty lest we, and our languages and cultures, become like the moa $^{2}$ bird; extinct.

The extinct large flightless bird the moa is used in the Māori vernacular as an analogy to describe any thing whose survival is threatened. 


\section{References}

Freire, Paulo 1993, Pedagogy of the Oppressed, Penguin: London.Higgins, Rawinia, R., 2004, "He Tānga Ngutu, He Tūhoetanga - Te Mana Motuhake o te Tā Moko Wahine: The Identity Politics of Moko Kauae" PhD Thesis, University of Otago.

hooks, bell, 1994 Teaching to Transgress - Education as the Practice of Freedom, Routledge:New York.

Johnston, Patricia Maringi G., 2004, "When Indigenous knowledge questions the limits: A lesson about wisdom" http://herdsa2004.curtin.edu.my/Contributions/Keynote s/KeynotePatriciaJohnston.pdf

Ka'ai, T. M. \& Higgins, R. R. Te Ao Mãori in Ka'ai, T., Moorfield, J., Reilly, M., Mosley, S., (eds.) 2004, Ki te Whaiao - An Introduction to Māori Society, Pearson Education New Zealand.

Ka'ai, T., 2000, Ngā Hua o te Mātauranga Māori i roto i te Whare Wānanga: The Value of Māori Studies in the University, Inaugural Professorial Lecture, University of Otago, pp1-21.

Ka'ai, T., Moorfield, J., Reilly, M., Mosley, S., (eds.) 2004, Ki te Whaiao - An Introduction to Mãori Society, Pearson Education New Zealand.

Mihesuah, D., and Cavendar, A. (eds.) 2004, Indigenizing the Academy-Transforming Scholarship and Empowering Communities, University of Nebraska Press: Lincoln.

Kāretu, T., Olsen-Ratana, T., Tawhiwhirangi, I., 2012, WAI 2336: Submission of Counsel for the Claimants. Unpublished Submission.

Webster, S., 1998, Patrons of Mãori Culture-Power, Theory, and Ideology in the Mãori Renaissance. Dunedin: University of Otago Press.

West, Cornel, 1999, The Cornel West Reader, Basic Civitas Books: New York. 